\title{
PREGLED RAZVOJA ZAVIČAJNE ZBIRKE GRADSKE KNJIŽNICE I ČITAONICE "METEL OŽEGOVIĆ" VARAŽDIN S NAGLASKOM NA NJEZINE POSEBITOSTI
}

Ovim radom želi se naglasiti važnost i uloga zavičajne zbirke u očuvanju svih aspekata zavičajne baštine na teritoriju sjeverozapadne Hrvatske. Navodeći kriterije koji su važni za nabavu i odabir građe te načine njene obrade i spremanja, dobiva se uvid u kompleksnost poslova kojima se mora pristupiti pri formiranju jedne takve zbirke. Nabrajanjem pojedinih djela ukazuje se na njezinu vrijednost te se pritom vodi briga o njezinoj zaštiti i dostupnosti na mrežnim stranicama Knjižnice.

\section{UVOD}

Zavičajne zbirke zauzimaju posebno mjesto u životu jedne zajednice, čuvajući posebno njenu kulturnu baštinu i određujući njezin identitet. Osnivaju se pri svim baštinskim ustanovama - knjižnicama, muzejima i arhivima, posebno pri narodnim knjižicama. Formiranje zavičajne zbirke iziskuje stručno osposobljeno osoblje, dugotrajan istraživački rad na prikupljanju građe, jasnu koncepciju, nabavu i selekciju, obradu i na kraju zaštitu građe. Građa takve zbirke prati rast jednog lokaliteta od samih početaka, objedinjujući na jednom mjestu knjižnu i elektroničku građu te obuhvaćajući prirodne, geografske, socioekonomske, kulturne i umjetničke značajke područja za koje se prikuplja. Izniman je izvor za 
proučavanje svih segmenata života, stoga se njome služe znanstvenici, novinari te razni istraživači prilikom izrade stručnih radova, monografija, filmova, izložbi, strategija razvoja. Iz toga proizlazi njezina kulturna, praktična, dokumentacijska i umjetnička vrijednost. Danas se mnoge škole i njima pripadajuće knjižnice potiču na sakupljanje i čuvanje građe karakteristične za podneblje u kojem obavljaju svoju obrazovno-odgojnu zadaću. Dobar je primjer Osnovna škola „Visoko”, koja čuva građu iz obližnje utvrde Čanjevo. Mnoštvo arheološkog materijala pohranjeno je u vitrinama i dostupno svakodnevno učenicima i djelatnicima te škole, kao i drugim zainteresiranim građanima. Izuzetan je primjer približavanja lokalne povijesti djeci od samog polaska u školu, a u neposrednoj je svezi s knjigom i promicanjem čitanja jer se zbirka nalazi u školskoj knjižnici. Sam izraz 'zavičajna zbirka' (engl. local collection, local studies, local history collection) označava zbirku odabrane, prikupljene, sređene i obrađene građe bilo koje vrste, koja se svojim sadržajem odnosi na određeno zemljopisno područje. Riječju 'zavičaj' označavamo mjesto pripadanja, ali prilikom prikupljanja građe moramo odrediti granice, bilo povijesno-zemljopisne bilo administrativne. Kako bi se osigurala izgradnja zavičajnih zbirki te stvaranje nacionalne zbirke knjižnične građe kao kulturnog dobra, pravnom je normativom regulirana dostava obveznog primjerka s područja županije u kojoj se knjižnica nalazi. ${ }^{1}$

\section{ZAVIČAJNA ZBIRKA WARASDINIENSIA}

\section{Osnivanje Zbirke}

Zavičajna zbirka Warasdiniensia najvrednija je posebna zbirka Gradske knjižnice i čitaonice "Metel Ožegović”. lako je prikupljanje građe počelo već 50-tih godina 20. stoljeća, javnosti je predstavljena 1968. godine zajedno s llirskom zbirkom. Tom prilikom proslavljena je 130. godišnjica osnivanja javne knjižnične djelatnosti u Varaždinu uz još nekoliko značajnih jubileja među kojima su 140. godišnjica osnivanja Muzičke škole te 80 . godišnjica rođenja varaždinskog pjesnika Zvonka Milkovića.

1 Zakon o knjižnicama i knjižničnoj djelatnosti, Narodne novine, 20. veljače 2019., 7-8. 


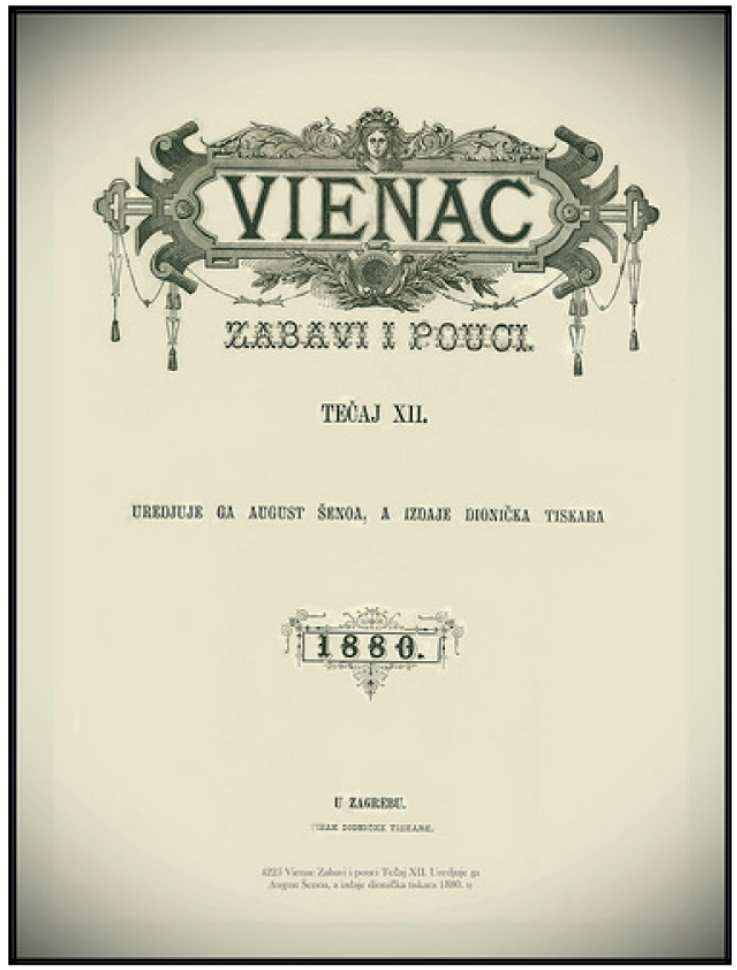

Slika 1. Naslovnica časopisa Vienac zabavi pouci, 1880. godina, GKČ „Metel Ožegović”

Zbirka je nazvana Warasdiniensia, po člancima objavljivanim u Viencu zabavi i pouci iz 1880. godine koje je objavljivao Ivan Milčetić, iako je tamo naveden naziv s jednostrukim V. ${ }^{2}$ Od samog osnivanja Zbirka je imala regionalan karakter i obuhvaćala je područje sjeverozapadne Hrvatske, odnosno područje Zajednice općina Varaždin. Tako su u njezin opseg ulazile općine Čakovec, Ivanec, Ludbreg i Novi Marof, što znači da je zadirala u područje Podravine, Hrvatskog zagorja i Međimurja, dijelove Hrvatske koji su bili ekonomski i kulturno izuzetno povezani. Ovakva koncepcija pokazala se opravdanom jer su mnoge knjižnice tek u novije vrijeme počele prikupljati građu za zavičajne zbirke, a doprinos tome dao je i nedostatak stručnog osoblja, prostora te smjernica za nabavu i obradu.

2 Ivan Milčetić (1853-1921.)- hrvatski književni povjesničar, filolog, etnograf i folklorist. 


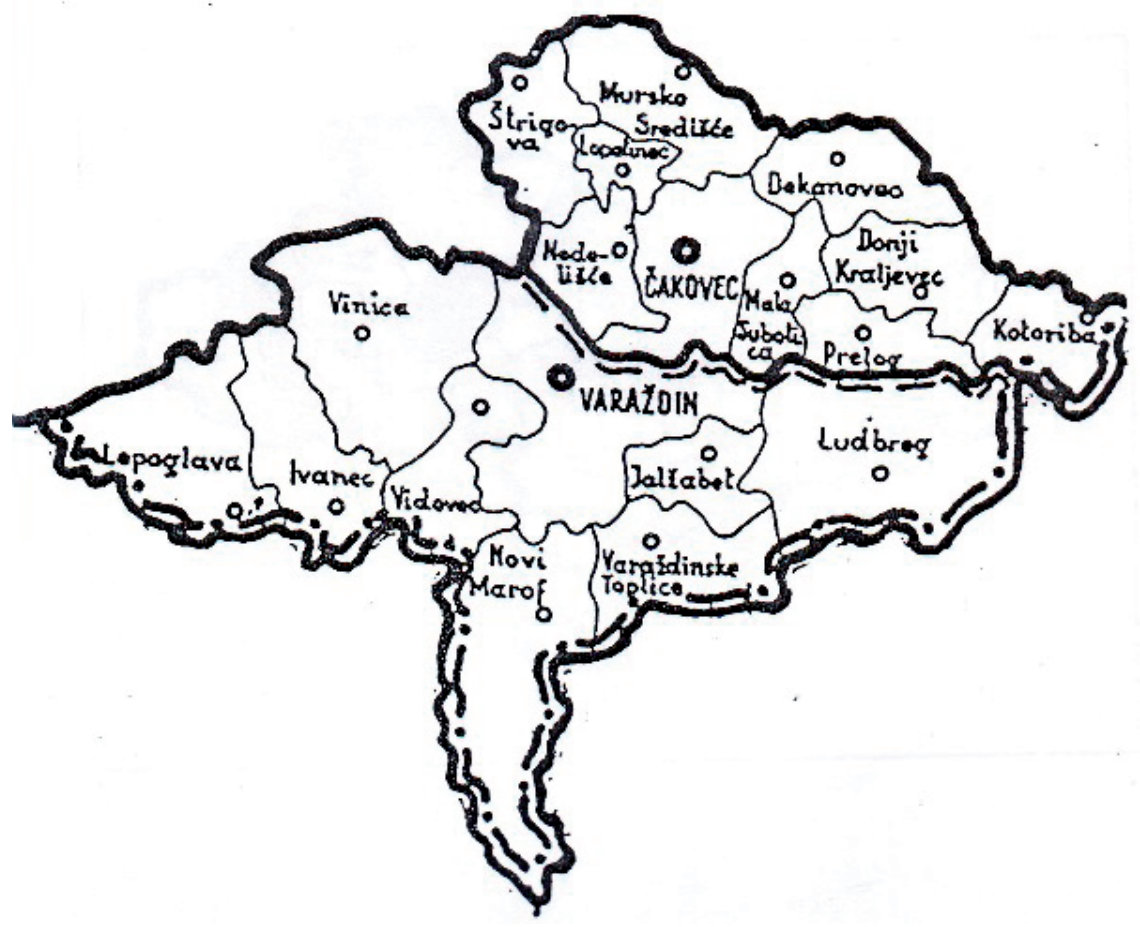

Slika 2. Područje dviju najsjevernijih županija

S novim teritorijalnim ustrojem Republike Hrvatske i uvođenjem županija 1990. godine došlo je do promjena u regionalnom karakteru Zbirke te ona od tada obuhvaća područje Varaždinske županije u kojoj su 22 općine i 6 gradova. Knjižnica u Čakovcu počinje tada sustavno prikupljati građu, dok knjižnice u Novom Marofu, Ivancu, Ludbregu i Lepoglavi postepeno formiraju svoje zavičajne zbirke. Gradska knjižnica kao matična knjižnica za sve narodne i školske knjižnice na području Varaždinske županije potiče osnivanje zbirki i prikupljanje građe te vodi računa o mogućem preklapanju građe.

\section{Nabava građe}

Prilikom prikupljanja građe za zavičajne zbirke poštuju se određeni kriteriji:

1. Građa je djelo autora rođenog na području zavičaja bez obzira na njegovo kasnije prebivalište. Tu pripadaju djela čiji su autori svojim djelovanjem, radom ostavili izniman trag na tom području. 
2. Građa koja se sadržajem odnosi na područje zbirke. To mogu biti djela koja su izdana bilo gdje u svijetu, na bilo kojem jeziku, a odnose se na sva područja znanosti.

3. Građa otisnuta na području Varaždinske županije - kao godina prekretnica za ovaj kriterij uzima se 1945 . godina, jer nakon 2. svjetskog rata dolazi do komercijalizacije nakladničke djelatnosti te rasta broja tiskara i nakladnika.

U Zbirku su uvršteni i autori koji su pohodili varaždinsku gimnaziju ili predavali na njoj u pojedinim razdobljima, djelujući tako na velik broj njezinih učenika, a time i na tijek povijesnih događanja. Zbog toga se tu nalaze djela Ksavera Šandora Gjalskog i ostalih manje poznatih učenika te učitelja čije bi se knjige po kriteriju zastarjelosti trebale izlučiti iz posudbenog fonda.

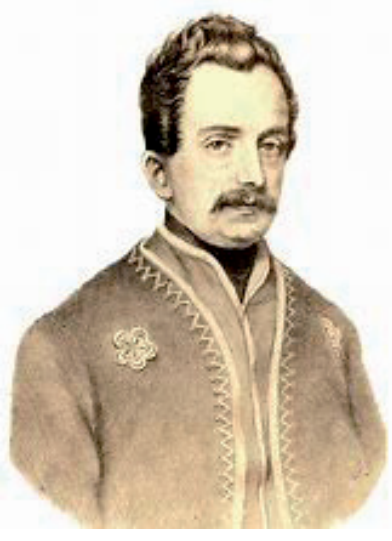

Slika 3. Ljudevit Gaj (1809-1872)

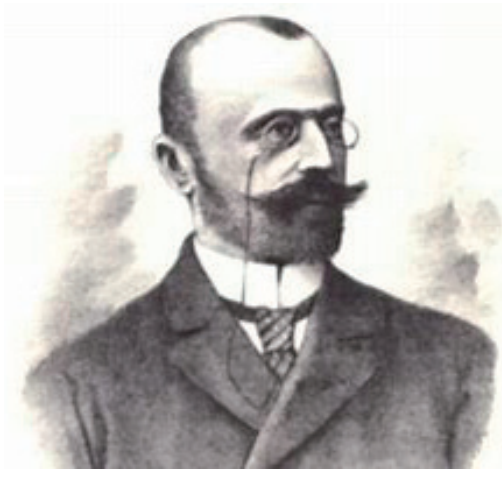

Slika 4. Ksaver Šandor Gjalski (1854 - 1935)

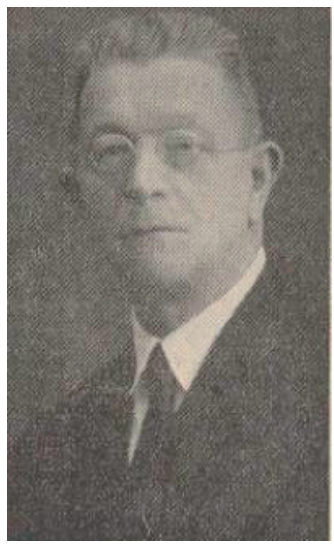

Slika 5. Krunoslav Babić (1875 - 1953)

Skupna djela u kojima se nalaze pojedini naslovi zavičajaca također se uvrštavaju u Zbirku. Svjesni velikog opsega djela te mnogih autora čija djela nisu uvrštena u Zbirku, prišlo se 2008. godine sustavnom popunjavanju, odnosno kompletiranju Zbirke nezastupljenim autorima i pojedinim djelima. Tako se od početnog slova abecede počeo revidirati popis autora. Djela pojedinih autora prebacivana su iz osnovnog fonda te pribavljana kupnjom i poklonima. Nastojalo se na jednom mjestu objediniti sva izdanja i sve naslove pojedinih autora 
te istraživačkim radom pronaći što više autora koji su svojim rođenjem ili djelovanjem trebali ući u fond Zavičajne zbirke. Za uvrštavanje građe otisnute na području županije uzima se kao godina prekretnica 1945., tj. kraj Drugog svjetskog rata, međutim nakladnički pothvati, posebna izdanja kao npr. Jansonova Povijest umjetnosti, lokalnog nakladnika Stanek, ušla su internim uputama u sastav Zbirke. Pojedina djela novih nakladnika (Katarina Zrinska, Tonimir) također su se uvrštavala u Zbirku kako bi se dobio uvid u nakladničku djelatnost na području Županije. Taj se kriterij zbog povećane produkcije postepeno napustio, iako se još uvijek prate izdanja institucija visokog školstva, kao što su FOI, Građevinski fakultet, Veleučilište u Varaždinu, koje uz pojedine tiskare dostavljaju redovno obavezni primjerak.

Tijekom godina se iznimna pažnja poklanjala nabavljanju djela tiskanih u prvim varaždinskim tiskarama. Pritom se surađivalo s antikvarijatima, kolekcionarima i građanima, a pratila se ponuda i na mrežama te raznim aukcijama.

\section{Vrste građe}

Zavičajna zbirka u svom fondu objedinjuje sve vrste knjižnične građe u svim formatima i na svim medijima. Fond čine monografske i serijske publikacije, kartografska građa (planovi grada, zemljopisne karte), polupublikacije (mnoštvo radnih materijala sa sjednica), sitni tisak, grafička građa (razglednice, fotografije), notna građa, audiovizualna i elektronička građa. S obzirom na sadržaj ona je najsloženija knjižnična zbirka.

Posebna pažnja pridaje se sitnom tisku koji iziskuje izuzetan trud prilikom prikupljanja i obrade. Skupljaju se leci, presavici, brošure, plakati, pozivnice, ulaznice koje svjedoče o kulturnoj djelatnosti grada, tj. učestalosti i obimu raznih priredbi. Tako se objedinjuju kronologije pojedinih kulturnih institucija (Gradskog muzeja, Hrvatskog narodnog kazališta, Hrvatske akademije znanosti i umjetnosti Zavoda za znanstveni rad u Varaždinu, Koncertnog ureda Varaždin), a ujedno se prati rad pojedinih udruga, organizacija, raznih tribina i sajmova itd. 


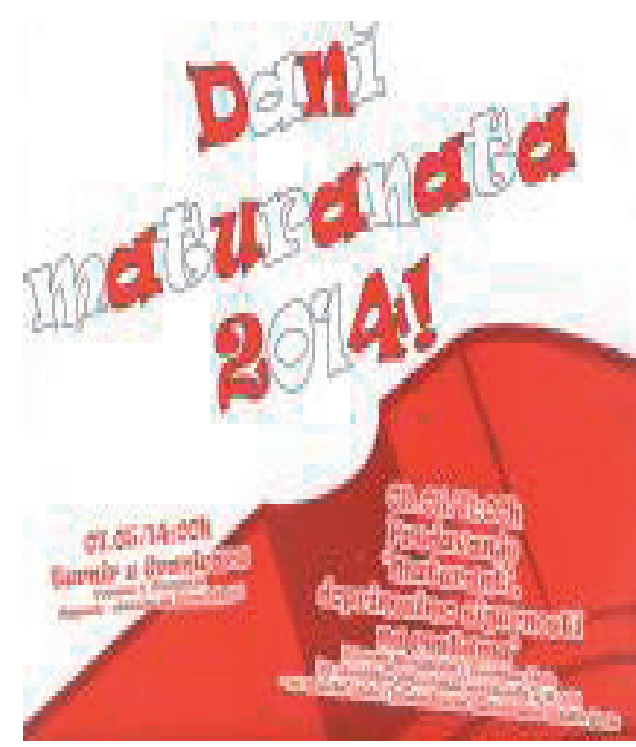

Slika 6. Naslovnica letka za manifestaciju Dani maturananta, GKČ „Metel Ožegović“ Varaždin
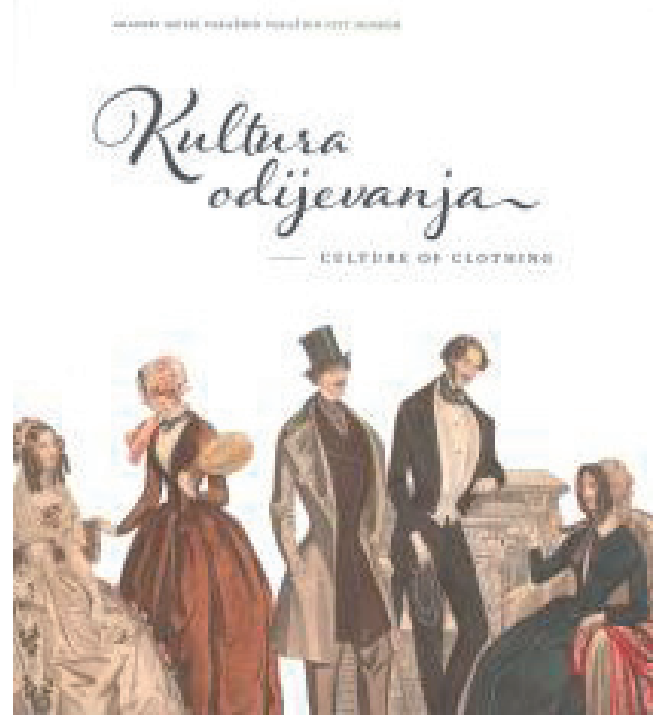

Slika 8. Katalog izložbe Gradskog muzeja Varaždin, GKČ „Metel Ožegović“ Varaždin

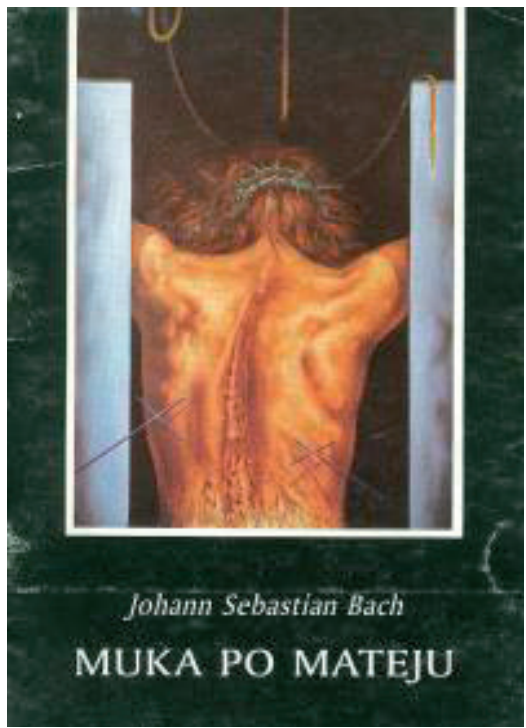

Slika 7. Program koncerta Zagrebačke filharmonije održanog u Isusovačkoj crkvi, GKČ „Metel Ožegović“ Varaždin

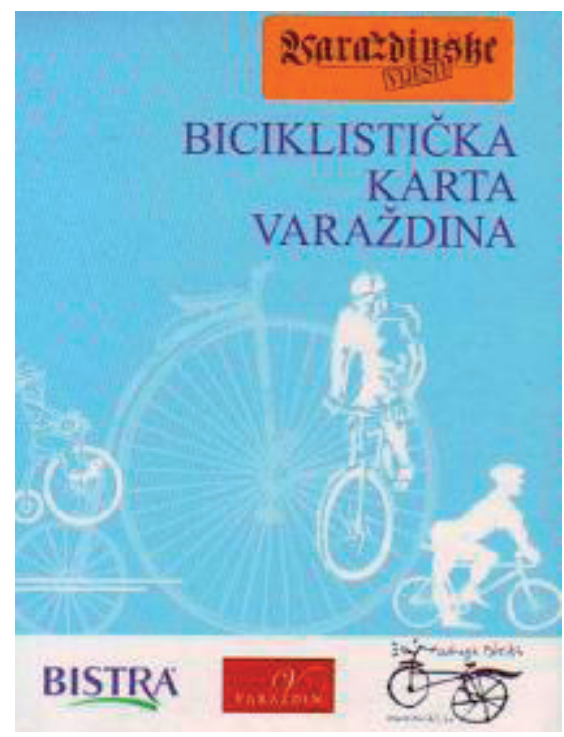

Slika 9. Prilog Varaždinskih vijesti, GKČ „Metel Ožegović Varaždin 


\section{Obrada građe}

Građa u Zavičajnoj zbirci obrađena je prema UDK međunarodnom klasifikacijskom sustavu, a sistematska je obrada započela 1969. godine, nakon što su se izradili mjesni, abecedni i stručni katalog. Nakon obrade monografske građe pristupilo se obradi članaka, studija i rasprava u časopisima, kalendarima te zbornicima paralelno s obradom serijskih publikacija iz osnovnog fonda Gradske knjižnice. U doba kada nije postojala računalna obrada podataka ni pretraživanje online kataloga, izuzetna su vrijednost bile informacije do kojih se dolazilo na vrlo brz i detaljan način. Velik broj članaka trebalo je povezati pomoću sustava predmetnih odrednica i pododrednica, stoga je formirana predmetna odrednica Varaždin. Ona je imala i niz pododrednica koje su označavale pojedine pojmove te područja znanosti, npr. Varaždin - arheologija, arhitektura, etnografija... Predmetne odrednice formirane su i za ostala područja: Varaždinske Toplice, Novi Marof i dr.

Od 1995. godine građa se računalno obrađuje, no i dalje se izrađuju klasični katalozi kako bi popisi građe bili dostupni i onima koji se tek navikavaju na računalnu tehnologiju. Zahvaljujući tome građu Zavičajne zbirke moguće je pretraživati ne samo preko računalnog kataloga Knjižnice već i preko internog mjesnog kataloga na listićima. Svaka vrsta građe ima svoju knjigu inventara, a od 2011. vodi se posebna knjiga za kupljenu, odnosno poklonjenu građu. Također, ispred signaturne oznake publikacije nalazi se oznaka VAR, koja pokazuje da se radi o posebnoj zbirci čije je korištenje dozvoljeno samo unutar prostorija Knjižnice. Promjene u klasifikaciji građe usklađuju se s osnovnim fondom Gradske knjižnice.

\section{Smještaj građe}

Građa raznih formata, veličina i obima, pohranjena na raznim medijima, iziskuje poseban prostor i opremu kako bi se pravilno smjestila, to jest uložila. Warasdiniensia je smještena u posebnoj prostoriji, u ormarima zaštićenima staklom. Plakati se nalaze unutar velikih omotnica i ulažu se u posebno uske i duge ladice. Sitni tisak sprema se u folije A4- i A3-formata, a potom u registratore označene pripadajućom signaturom. Serijske publikacije u obliku uvezenih knjiga ili snopića ulažu se na posebne police. Elektronička građa nalazi se izdvojena u posebnim kutijama, označena i spremljena u ormare. Najveći izazov predstavlja kvalitetno spremanje sitnog tiska, posebno plakata te grafičkih monografija neobičnih dimenzija. Prostorije u kojima se građa nalazi zaštićene su od direktnog izlaganja suncu, redovito prozračivane te opremljene odvlaživačima zraka. 


\section{Posebnosti građe Zavičajne zbirke}

Od pregršt vrlo vrijedne građe koja se nalazi u Zbirci svakako je potrebno izdvojiti rukopisnu građu o osnivanju i djelatnosti prvih čitaonica te knjižnica u Varaždinu. Pravila društava, Pravila posudbe, Knjige članova i Knjige inventara, zajedno s ostalim dokumentima, nepresušan su izvor za proučavanje početaka knjižnične djelatnosti, ali i svjedok vremena iz kojeg učimo o običajima, navikama i željama građana Varaždina.

Tamo su i naslovi koji su otisnuti u prvim tiskarama Grada. Tako pratimo tiskarsku djelatnost Ivana Manliusa, Tomaša Trattnera, Ivana Sangille, Josipa Platzera i Ivana Krstitelja Stiflera.

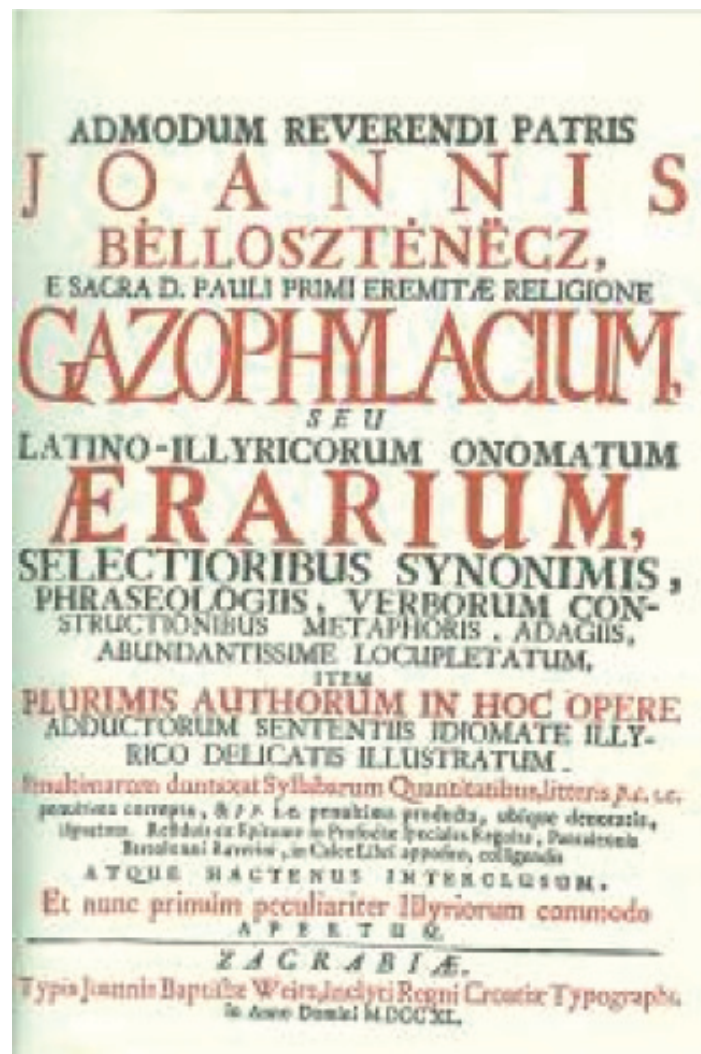

Slika 10. Naslovnica Gazophylaciuma, djela Ivana Belostenca izdanog 1740. godine, GKČ „Metel Ožegović” Varaždin 
Najstarije djelo u Zbirci jest Gazophylacium, latinsko-hrvatski i hrvatsko-latinski rječnik Ivana Belostenca, objavljen u Zagrebu 1740. godine. U njemu je Belostenec uspio na jednom mjestu okupiti sva tri hrvatska narječja, čime se svrstao u struju koja je težila ostvarenju jedinstvenog književnog jezika. Djelo je ležalo u pavlinskom samostanu u Lepoglavi i čekalo na objavu punih 65 godina.

Prva tiskana povijest grada Varaždina djelo je Ladislava Ebnera, gradskog notara i predsjednika Sudbenog stola Varaždinske županije.

Medicina ruralis iliti Vrachtva ladanyszka : za potrebouchu musev y sziromakov horvatczkoga orszaga y okolo nyega, blisnesseh meszt, prva je tiskana medicinska stručna knjiga na hrvatskom jeziku otisnuta kod Ivana Tomaša Trattnera. Autor je Ivan Krstitelj Lalangue, županijski liječnik u Varaždinu koji u središte radnje stavlja hrvatskog seljaka sa svim njegovim nedaćama.

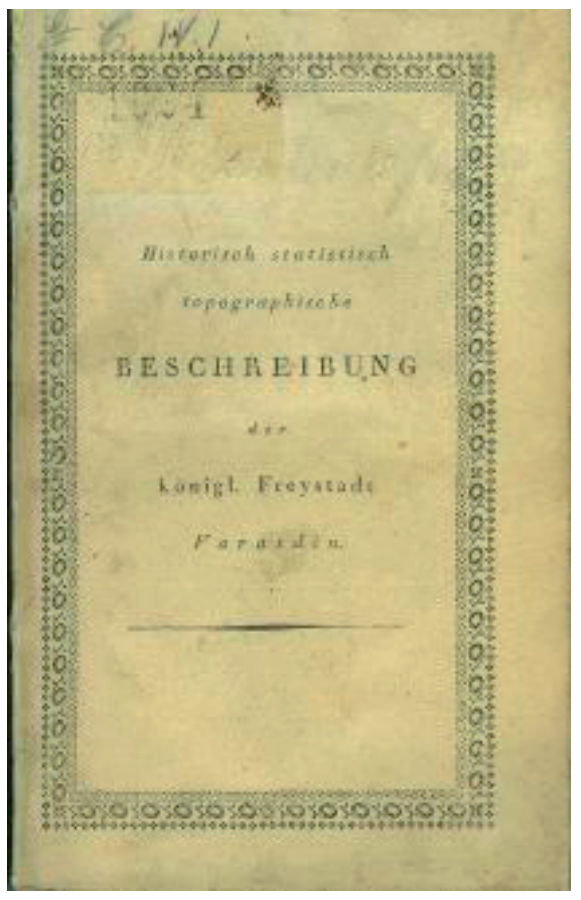

Slika 11. Ladislav Ebner, Historisch statistisch topographische Beschreibung der koenigl. Freystadt Varasdin, tiskano u Varaždinu kod Ivana Sangille 1848. godine, GKČ „Metel Ožegović”

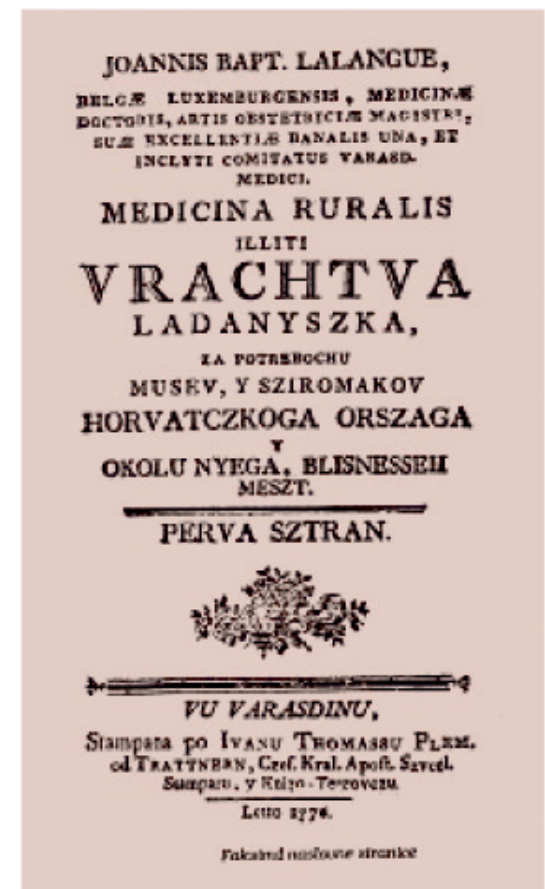

Slika 12. Joannis Bapt. Lalangue, Medicina ruralis iliti Vrachtva ladanyszka : za potrebochu musev y sziromakov horvatczkoga orzsazga y okolo nyega... , tiskao Ivan Thomas plem. Trattner 1776. godine, GKČ „Metel Ožegović" 


\section{Zbirka razglednica, fotografija i dopisnica}

Intenzivnije prikupljanje razglednica započelo je nakon 2008. godine, a danas je grafička građa prepoznata kao vrijedan i vjerodostojan dokument o izgubljenim arhitektonskim karakteristikama nekadašnjeg izgleda ulica, trgova te kuća Varaždina i okolice. Razglednice se spremaju u posebne omotnice i zatim ulažu u kronološki formirane albume - one nastale prije i poslije Drugog svjetskog rata. Ponekad je vrlo teško odrediti točan datum nastanka, pa se pritom koristi žig, poštanska marka ili datum koji je pošiljatelj naveo. Abecednim redoslijedom poredane su od Bednje, Bele, pa sve do Varaždinskih Toplica i Trakošćana. Ne prikupljaju se samo motivi varaždinskih ulica i trgovina, već i motivi cijelog zavičaja, a jedan manji dio razglednica može se pregledati na mrežnim stranicama, dok nas u budućnosti čeka njihova detaljnija obrada. Osim toga čuvaju se i čestitke te dopisnice nastale u radionicama zavičajnih likovnih umjetnika.

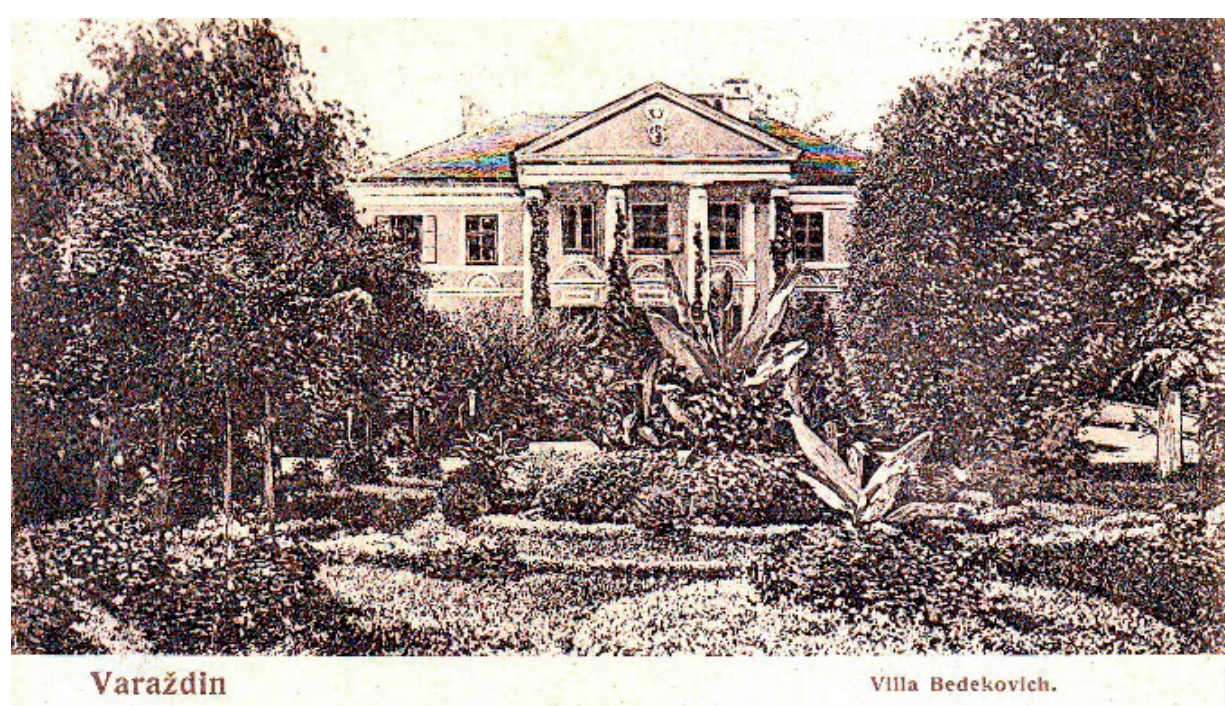




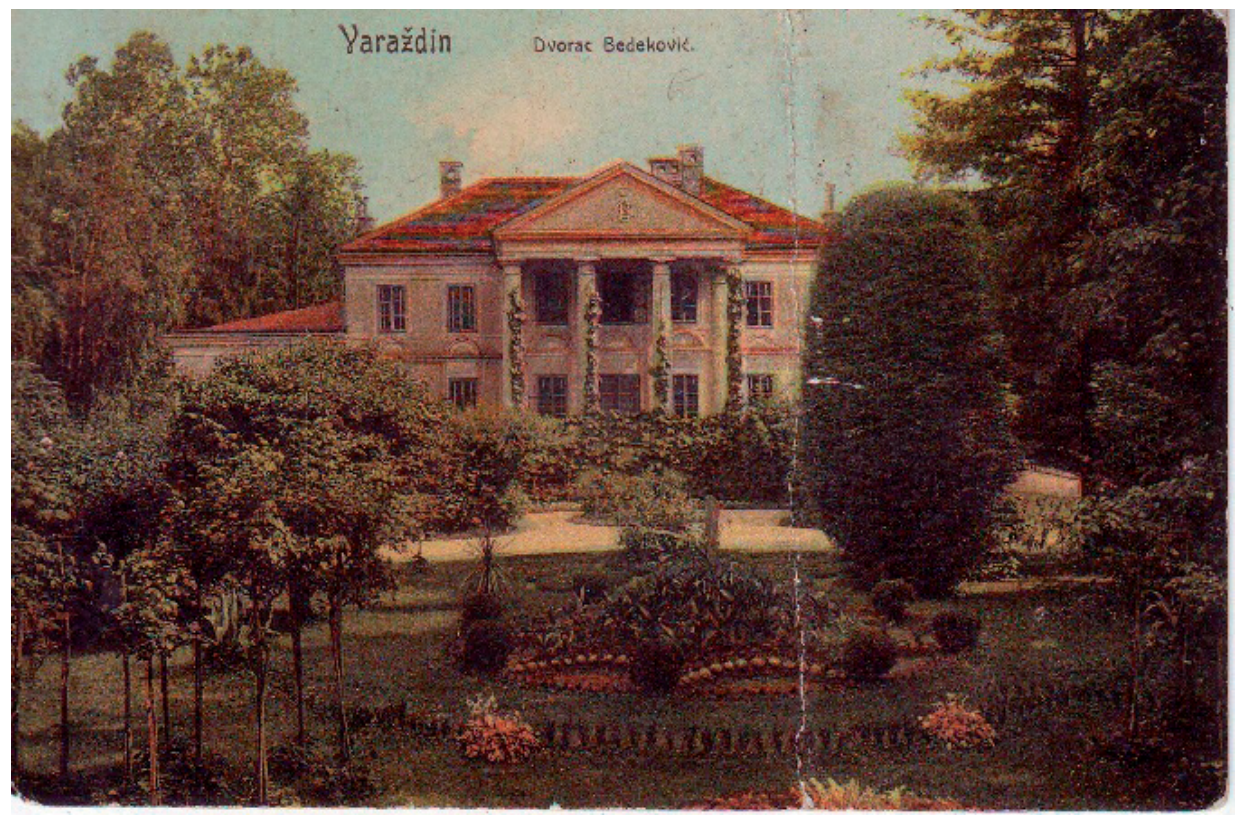

Slika 13. i 14. Vila Bedeković na starim razglednicama, GKČ „Metel Ožegović” Varaždin

\section{Zaštita zavičajne građe}

Nakon početnog mikrofilmiranja u 90-im godinama krenula je eksperimentalna digitalizacija zavičajnih novina pri kojoj su 2004. digitalizirane Varaždinske novosti (1929 - 1941) i Varaždinske vijesti (1945 - 1961). Sadržaj se prvotno mogao samo pregledavati, ali ne i pretraživati. Intenzivnije se digitalizaciji prišlo 2008. godine, nakon što su se projektu Digitalizacija zavičajne baštine pridružili Gradski muzej i Državni arhiv sa svescima novina koje su nedostajale. Ministarstvo kulture također se uključilo. Do danas su digitalno obrađeni najstariji naslovi knjiga, brošura i novina, ukupno 102263 stranica, veličine 975261 GB-a.

\section{LITERATURA}

1/ Marijan KRAŠ, „Warasdiniensia“ - Zavičajna zbirka, Godišnjak Gradske knjižnice i čitaonice „Metel Ožegović" Varaždin, 1, Varaždin, 1995., 63-67.

2/ Vanda MILČETIĆ, „Dvije zbirke Gradske knjižnice i čitaonice u Varaždinu“, Knjiga i čitaoci, 3-4, Zagreb, 1970., 12-14.

3/ Andreja TOLJAN, „Warasdiniensia“ - pregled razvoja zbirke od početaka do primjene multimedijalnog sustava", Varaždin, 1999. 


\section{SAŽETAK}

\section{PREGLED RAZVOJA ZAVIČAJNE ZBIRKE GRADSKE KNJIŽNICE I ČITAONICE „METEL OŽEGOVIĆ" VARAŽDIN S NAGLASKOM NA NJEZINE POSEBITOSTI}

Zavičajna zbirka Gradske knjižnice i čitaonice „Metel Ožegović” najvrednija je zbirka u Knjižnici, predstavljena javnosti 1968. godine. Od prvih momenata prikupljanja građe, izradom kataloga, marljivim i pronicljivim radom tadašnjih djelatnika, zajedno s ravnateljicom Vandom Milčetić, težila je postati jednom od najcjelovitijih i najkvalitetnije obrađenih zavičajnih zbirki. Tijekom godina uvijek se obradi i nabavi građe Zbirke pristupalo na odgovoran i inspirativan način. Unatoč ponekim teškoćama prilikom nabavljanja, selektiranja i obrade, koje su uvjetovane njezinim izdavanjem, oblikom i vrstom, Zbirka je stekla status jedne od najbogatijih građom o svim područjima djelovanja na području šireg zavičaja.

Od 2008. godine intenzivno se popunjavala djelima autora koja joj nedostaju, neumorno istražujući povijest, kulturu i znanost kako bi pronašla što više zaslužnih zavičajaca. Danas, od početnih 1000 naslova, Zbirka broji preko 10000 svezaka, obrađujući sve vrste građe u nekoliko knjiga inventara. Daljnjim postupcima digitalizacije građa se štiti od čestog korištenja te nudi pristup dokumentima i vrelima koji su do tada bili nedostupni.

Kroz izložbe, promocije i obljetnice Knjižnica promovira svoju građu te zajedno u suradnji s brojnim institucijama doprinosi važnosti očuvanja vlastite kulturne posebnosti. Svojim sadržajem ona je nepresušno vrelo istraživanja učenika, profesora, znanstvenika te je njezina vrijednost dokumentacijska, kao i umjetnička.

Ključne riječi: Zavičaj; zavičajne zbirke; baština; knjižnice; digitalizacija. 


\section{SUMMARY}

\section{EXPANSION SURVEY OF THE REGIONAL COLLECTION OF METEL OŽEGOVIĆ PUBLIC LIBRARY IN VARAŽDIN WITH THE EMPHASIS ON ITS SPECIFICITIES}

The regional collection of „Metel Ožegović“ Public Library is the most valuable collection in the Library, which was first presented to the public in 1968. From the first moment it strived to become one of the most complete and high quality catalogued regional collections by collecting materials, designing catalogues, by diligent and shrewd work of its librarians together with Vanda Milčetić, the library director at that time. The materials have always been collected and catalogued in a responsible and inspirational way. Despite some problems while collecting, selecting and cataloguing materials, which have been caused by their publication, shape and kind, the Collection has gained its irrefutable status both in the regional area and outside its boundaries.

Since 2008 the Collection has been completed systematically by authors which have not been included in the collection so far as well as by works of already included authors. The materials have been collected by purchase, donations, presents and by researching history, culture and science unflaggingly in order to find as many regional items as possible. At first the Collection included 1,000 titles while today it amounts to 10,000 volumes, by cataloguing all kinds of materials which have been entered into several inventory books. By further process of digitalization the materials have been protected from frequent usage and the access to some documents and sources which have been inaccessible so far has been provided.

Through exhibitions, promotions and anniversaries the Library has promoted its materials and it has contributed to the importance of the protection of its own cultural features together with many other institutions.

Its content provides an inexhaustible source of research for many students, teachers and scientists so its value is both documentary and artistic.

Key Words: Region; regional collections; heritage; public libraries; digitalization. 